\title{
Rootplowing, Front-end Stacking, and Seed- ing Effects on Herbaceous Plant Species Composition
}

\author{
C.L. GONZALEZ AND G.V. LATIGO
}

\begin{abstract}
Effects on herbaceous plant species composition of two mechanical brush manipulation treatments (rootplowing and front-end stacking) with and without grass seeding were investigated in the Rio Grande Plain of Texas. Clearing of brushy rangeland by either rootplowing or front-end stacking increased native grass and forb diversity. During the first year after treatment, forbs accounted for about $70 \%$ of plant species composition based on density, but by the third and fifth year, they decreased to $25 \%$. Plots seeded to native or introduced grasses established good stands, and by the second year, desirable forage had increased. Buffelgrass (Cenchrus ciliaris), an introduced seeded species, was the most aggressive species. Five years after mechanical brush manipulation, this species accounted for a major portion of the plant composition in both seeded and nonseeded treatments.
\end{abstract}

The vegetation of much of the Rio Grande Plain of Texas has changed greatly since domestic livestock were introduced over 100 years ago. Generally, perennial grasses have decreased and shrubs such as mesquite (Prosopis glandulosa), blackbrush acacia (Acacia rigidula) and cacti (Opuntia Spp.) have increased. Although the quality of management has improved greatly on most range within the last two or three decades, most rangeland is still below its forage production capacity (Texas Conservation Needs Committee 1974).

Although some believe that the brush invasion is recent, reports on the early vegetation of the Rio Grande Plain indicated that brush species always have been present although in limited size and density (Johnston 1963; Inglis 1964; Lehmann 1965). In the Rio Grande Plain of Texas, about $85 \%$ ( 5.5 million ha) of the area supports at least a $20 \%$ woody canopy cover (Smith and Rechenthin 1964).

Control of woody species by mechanical treatment is expensive, complex, and difficult, since many species occur on the same range site. Control is complicated because certain species may require different treatments at different times. In addition, some species are desirable wildlife food plants and should not be controlled.

Rootplowing, a mechanical manipulation practice that cuts off woody plants below ground by means of a horizontal blade pulled behind a tractor, generally at a depth of 35 to $40 \mathrm{~cm}$, has been highly effective in combating dense stands of mixed brush. In low rainfall areas, however, the practice could destroy a high percentage of existing desirable perennial grasses and result in the invasion of annual grasses and weeds (Fisher et al. 1959). Mathis et al. (1971) reported that in Throckmorton County, Texas, rootplowing decreased grass production for the next six growing seasons. In west Texas, Hughes (1966) reported more total production after rootplowing, but forbs and annual grasses constituted the major vegetation. In the Coastal Prairie of Texas, Powell and Box (1967)

\footnotetext{
Authors are range scientist and biological aid, U.S. Department of Agriculture Science and Education Administration, Agricultural Research, Soil and Water Conservation Research, Weslaco, Texas 78596.

Manuscript received July 19, 1979.
}

concluded that controlling brush with minimum soil disturbance was the best method for improving vegetative composition. However, they used natural plant succession; no artificial vegetation or seeding was used.

Fisher et al. (1959) reported that in northwest Texas, seeding grasses after rootplowing produced good stands of native and introduced grass species. On the rolling and Southern High Plains, however, Jaynes et al. (1968) reported that seeding native grasses after rootplowing often resulted in unsatisfactory stands.

Front-end stacking, a recently introduced mechanical practice, has not been thoroughly evaluated. A front-end stacker is a modified dozer blade using a toothed, rake-like "stacker" with teeth 14 to $36 \mathrm{~cm}$ apart. The teeth pull the plants out of the soil. In the Coastal Prairie of Texas, Powell and Box (1967) found that scalping, a manipulation similar to front-end stacking, decreased herbage production.

We conducted this study to investigate further the effects of rootplowing and front-end stacking with and without seeding on changes in species composition of herbaceous plant communities.

\section{Study Area}

The study area is on the southern edge of the Rio Grande Plain about $38 \mathrm{~km}$ north of Rio Grande City, Starr County, Texas. Long-term average annual precipitation is $43 \mathrm{~cm}$. Potential evaporation cxcceds precipitation by four fold (USDC 1970). Most precipitation occurs as thunderstorms that are unevenly distributed both geographically and seasonally. Occasionally, tropical disturbances produce heavy fall rains. Thus, September has the highest long-term monthly average. Another rainfall peak occurs in late May or early June from squall-line thunderstorms.

Summer temperatures are high, and daily maximum temperatures in July and August are usually $38^{\circ} \mathrm{C}$ or higher. Fall freezes occur 7 out of 10 years, and spring freezes occur 9 out of 10 years. The average length of the growing season is 305 days (USDC 1970).

The study area is a sandy loam soil range site with level to gently sloping topography ( 0 to $5 \%$ ). The associated soil types are McAllen and Brennan sandy loams. These soils have a noncalcareous fine sandy loam surface layer and a sandy clay loam subsoil. The Brennan series is a member of the fine-loamy, mixed, hyperthermic family of Aridic Haplustalfs; the McAllen series belong to the hyperthermic family of Ardic Ustochrepts. The fine sandy loam surface layer ranges from about 25 to $50 \mathrm{~cm}$ in depth. Permeability of the subsoil is moderate. The water holding capacity and fertility of these soils are high; thus, this site has a high production potential.

The dominant woody plant species include cenizo(Leucophyllum frutescens), blackbrush acacia, coyotillo (Karwinskia humboldtiana, coma (Bumelia celastrina), mesquite, and capul (Schaefferia cuneifolia.)

Dominant native grass species include Wright's threeawn (Aristida wrightii), Texas bristlegrass (Setaria texana), hooded windmillgrass (Chloris cucullata), and red grama (Bouteloua trifida). 
Forb cover is sparse; western ragweed (Ambrosia psilostachya), ragweed parthenium (Parthenium hysterophorus), rose palafoxia (Palafoxia rosea), and lazy daisy (Aphanostephus skirrhobasis) are most common.

\section{Methods}

Mechanical treatments were established during June, 1972, on native undisturbed brushland in poor range condition due to overgrazing. A randomized split block design had three replications of main plots of two mechanical brush-manipulation treatments (rootplowing and front-end stacking) and an undisturbed control. Each replication or block consisted of three 2.4-ha strips, one strip each for rootplowing, front-end stacking, and the control. Each strip was divided equally into three 0.8 -ha subplots, which were seeding treatments of (1) a single introduced species, buffelgrass (Cenchrus ciliaris), at $2.2 \mathrm{~kg} / \mathrm{ha}$, (2) a mixture of five native grass species (Table 1), and (3) nonseeded. Subplots were handseeded between August 31 and September 6, 1972.

Table 1. Five native grasses seeded as a mixture and corresponding seeding rates.

\begin{tabular}{lc}
\hline \hline Species & $\begin{array}{c}\mathrm{Rate}^{\mathrm{l}} \\
(\mathrm{kg} / \mathrm{ha})\end{array}$ \\
\hline Pink pappusgrass (Pappophorum bicolor) & 0.4 \\
Arizona cottontop (Digitaria californica) & 0.7 \\
Plains bristelgrass (Setaria macrostachya) & 0.4 \\
Two-flower trichloris (Trichloris crinita) & 0.3 \\
Four-flower trichloris (Trichloris pluriflora) & 0.3 \\
\hline
\end{tabular}

'Rates based on pure live seed.

All plots were deferred from domestic livestock grazing until winter, 1974. They were then grazed from late spring to early summer and again in late fall each year. The number of animal units varied each year, but plots were grazed for $90,140,135$, and 160 days for $1974,1975,1976$, and 1977 , respectively. Utilization of current growth was about $60 \%$ each year.

Woody plant canopy cover was determined using the line intercept method (Canfield 1942). Woody species density and relative frequency were determined before mechanical treatment by the point-centered quarter method (Dix 1961). Seventy-five points were established on each of the three 2.4-ha strips of brush for the point-centered quarter method and nine line transects $30 \mathrm{~m}$ long for the line intercept method. Changes in herbaceous composition were evaluated by point quadrat methods ( 20 quadrats per subplot). Herbaceous species data were collected twice yearly (June and November).

Plant nomenclature follows Vines (1960), Gould (1975), and Correll and Johnston (1970). Data were statistically analyzed by analysis of variance procedures (Cochran and Cox 1956). Dun-

Table 2. Woody plant species frequency and density before mechanical brush manipulation treatments in 1972.

\begin{tabular}{lcc}
\hline \hline Species & $\begin{array}{c}\text { Frequency } \\
(\%)\end{array}$ & $\begin{array}{c}\text { Density } \\
\text { (plants/ha) }\end{array}$ \\
\hline Cenizo (Leucophyllum frutescens) & 32 & 520 \\
Black brush (Acacia rigidula) & 27 & 500 \\
Coyotillo (Karwinskia humboldtiana) & 31 & 400 \\
Coma (Bumelia celastrina) & 25 & 480 \\
Capul (Schaefferia cuneifolia) & 21 & 350 \\
Cranjeno (Celtis pallida) & 20 & 280 \\
Sage (Salvia ballatafolia) & 19 & 280 \\
Guayacan (Porliera angustifolia) & 22 & 260 \\
Cactus (Opuntia Spp.) & 16 & 250 \\
Mesquite (Prosopis glandulosa) & 15 & 200 \\
$\quad$ Total major spp. & & 3520 \\
$\quad$ Misccllaneous spp. & & 1405 \\
$\quad$ Total spp. & & 4925 \\
\hline
\end{tabular}

can's multiple range test was used to test for individual comparisons.

\section{Pretreatment Conditions}

Before mechanical brush manipulation, the plant community was dominated by low-growing woody species including some cacti and a few grasses and forbs in the understory. A total of 28 woody species were identified. Total woody plant density was 4,925 plants/ ha (Table 2 ) with 10 species contributing 3,520 plant$\mathrm{s} /$ ha. This high woody plant density was associated with low herbaceous plant density and production. Woody plant canopy cover averaged $32 \%$. Cenizo and blackbrush acacia were dominant and accounted for 1,020 plants/ha. Cenizo and coyotillo had the highest relative frequency, 32 and $31 \%$, respectively.

The grass flora was composed of 16 species (Table 3). Four species accounted for $63 \%$ of the plant composition and 12 miscellaneous species combined accounted for $25 \%$. Texas bristlegrass, red grama, hooded windmill, and Wright's threeawn with frequency of occurrence values exceeding $25 \%$ were well distributed throughout the study area. All forbs accounted for $12 \%$ of the plant composition.

Table 3. Herbaceous plant species composition and frequency before mechanical brush manipulation in 1972.

\begin{tabular}{lcc}
\hline \hline & $\begin{array}{c}\text { Species } \\
\text { composition } \\
(\%)\end{array}$ & $\begin{array}{c}\text { Frequency } \\
(\%)\end{array}$ \\
Species & & \\
\hline Grasses & 13 & 31 \\
$\quad$ Red grama (Bouteloua trifida) & 37 \\
Hooded windmillgrass (Chloris cucullata) & 11 & 26 \\
Wright's threea wn (Aristida wrightii) & 14 & 36 \\
Texas bristlegrass (Setaria texana) & 25 & 14 \\
Gummy lovegrass (Eragrostis & & 10 \\
$\quad$ curtipedicillata) & 6 & 3 \\
Hall's panicum (Panicum hallii) & 6 & 7 \\
Buffelgrass (Cenchrus ciliaris) & 3 & 3 \\
Sand dropseed (Sporobolus cryptandrus) & 2 & 1 \\
Four-flowered trichloris (Trichloris & & 1 \\
$\quad$ pluriflora) & 1 & 9 \\
Fall witchgrass (Leptoloma cognatum) & 1 & \\
Pink pappus (Pappophorum bicolor) & 1 & \\
Miscellaneous grasses & 5 & 4 \\
Forbs & & \\
Western ragweed (Ambrosia psilostachya) & 4 & 3 \\
Wooly tidestromia (Tidestromia & & 1 \\
$\quad$ lanuginosa) & 2 & 2 \\
Ragweed parthenium (Parthenium & & 5 \\
$\quad$ hysterophorus) & 1 & \\
Rose palafoxia (Palafoxia rosea) & 1 & \\
$\quad$ Miscellaneous forbs & 4 & \\
\hline & & \\
\hline
\end{tabular}

\section{Precipitation}

Total annual precipitation amounts recorded were $86,60,55,73$, and $40 \mathrm{~cm}$ for 1973 to 1977 , respectively (Fig. 1). Precipitation during this period was above normal $(43 \mathrm{~cm})$ in all years except 1977.

Seasonal distribution of rainfall was irregular during the period from 1973 to 1976, a period when mean annual precipitation was above the record mean. It was below the mean during the winter season of all years, but 1973. In 1977, when mean annual precipitation was below the mean the winter mean was also below normal. The precipitation means in spring of 1973 and 1977 were different from the normal; 1973 was extremely dry, while 1977 was extremely wet. Annual precipitation for summer was above the record mean for all 5 years. All years but 1977 were characterized by extremely wet summers. Fall precipitation for 1973, 1974, and 1976 was above the mean; 1975 and 1977 was below. In 1977, no precipitation was received during the months of November and December. 

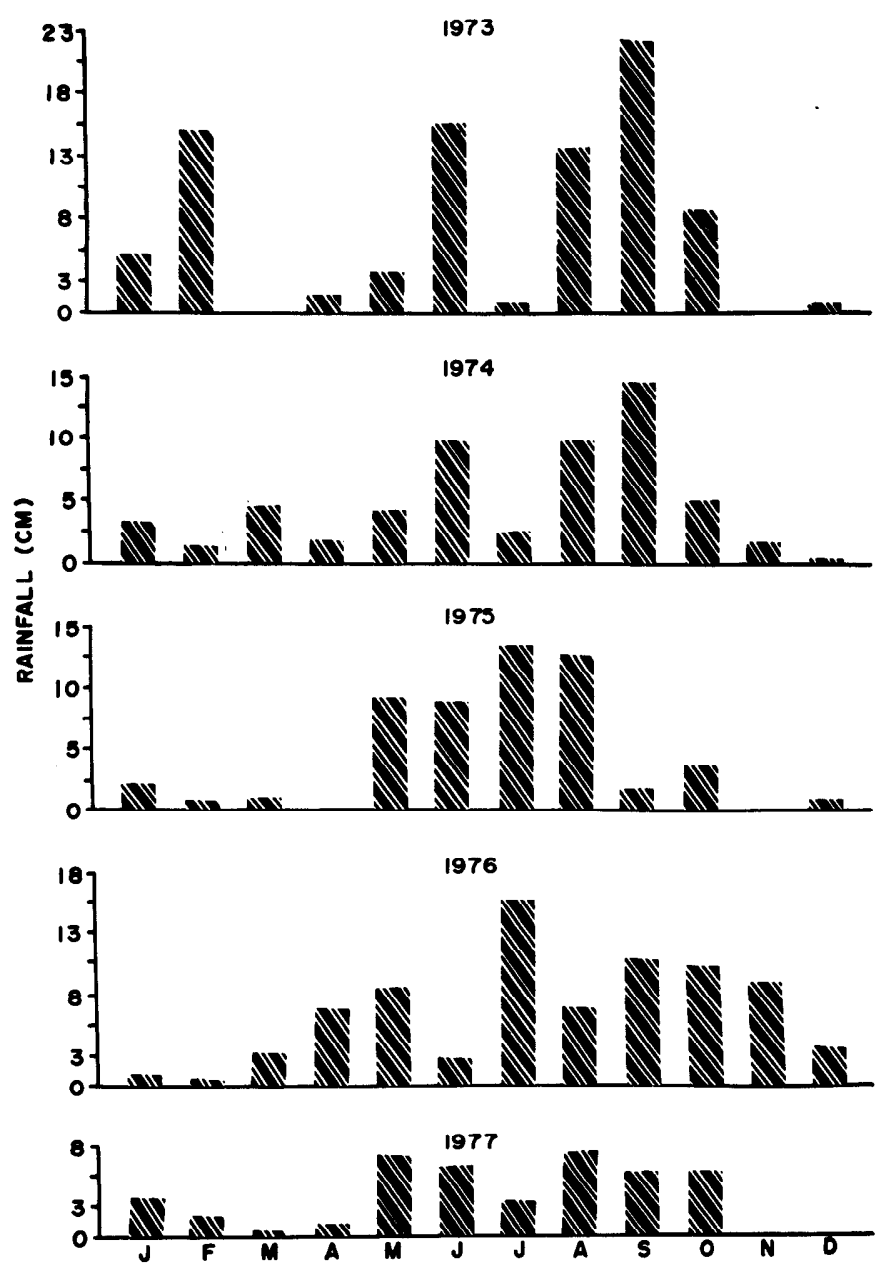

Fig. 1. Monthly precipitation record in study area from 1973 to 1977.

\section{Results}

\section{Herbaceous Composition}

The effect of mechanical treatments on plant species composition (PC) based on density and plant frequency (PF) as compared with an undisturbed control was variable (Tables 4,5 , and 6). Both mechanical manipulation treatments showed more forb density than the control for 3 years following treatment; however, after 5 years forb density was significantly higher only in the rootplowing treatment.

\section{Mechanical Manipulation (main treatments)}

In 1973, hooded windmillgrass acounted for the highest PC and plant frequency (PF) of all grass species in both mechanical brush manipulation treatments (Table 4). However, in the control treatment, red grama accounted for the highest PC $(20.8 \%)$ and hooded windmillgrass accounted for the highest frequency (51\%). Twoflowered trichloris, a seeded species, did not germinate or establish in any of the plots. The other five seeded species combined accounted for $8.7,5.2$, and $6.8 \%$ PC for rootplowed, front-end stacking, and control, respectively. Forb PC was high, $69.3 \%$ for rootplowed and $66.8 \%$ for front-end stacking, but accounted for only $26.8 \%$ PC for the control treatment.

Total number of plants/ha in 1973 was higher in front-end stacking and the control, as compared to rootplowed (Table 4). However, forbs such as western ragweed, ragweed parthenuim, rose palafoxia, and lazy daisy accounted for most plant numbers in both mechanical manipulation treatments. During periods of high rainfall, other species such as espanta vaqueros(Tidestromia lanuginosa), falsemallow (Malvastrum americanum), common verbena (Verbena hipinnatifida), and other annuals were common.

By 1975 , plant density had decreased in all main treatments (Table 5); the greatest reduction occurred in front-end stacking. Forb density only contributed to $18 \%$ PC in front-end stacking and was significantly lower than rootplowed treatment. The control treatment decreased by 3\% PC from 1973 but had higher PF than both mechanical manipulation treatments; this, however, was not significantly different.

Percent PC contributed by seeded species increased in all treatments in 1975. Percent PC of all five seeded species combined was 28.6, 19.0, and 19.0 for rootplowed, front-end stacking and the control, respectively. Buffelgrass and Arizona cottontop PC in rootplowed were significantly higher than both front-end stack and the control treatment. Three-flowered trichloris had the highest PC of all the seeded species in both mechanical manipulation treatments and was significantly different from the control. In the control treatment, three nonseeded grass species, red grama, hooded windmillgrass, and Wright's threeawn, contributed more than $37 \% \mathrm{PC}$ and were the most frequent.

Five years following treatment (1977), total plant density averaged 519,590 plants/ha for all main treatments (Table 6). The reduction in plant density can be attributed to a great reduction in forbs, especially in the mechanical manipulation treatments. In 1977 , forb PC was $32.1 \%$ for rootplowed as compared to 23.6 and $25.3 \%$ for front-end stacking and the control, respectively.

Table 4. Herbaceous plant species composition (PC) and plant frequency (PF) of major species for rootplowing (RP), front-ending stacking (S), and control (C) in 1973.

\begin{tabular}{|c|c|c|c|c|c|c|c|c|}
\hline \multirow[b]{2}{*}{ Species } & \multicolumn{2}{|c|}{ RP (\%) } & \multicolumn{2}{|c|}{$\mathrm{S}(\%)$} & \multicolumn{2}{|c|}{$\mathrm{C}(\%)$} & \multicolumn{2}{|c|}{$\mathrm{X}(\%)$} \\
\hline & $\overline{\mathrm{PC}}$ & PF & $\overline{\mathrm{PC}}$ & PF & $\overline{P C}$ & PF & $\overline{\mathrm{PC}}$ & PF \\
\hline$\overline{\text { Red grama (Bouteloua trifida) }}$ & $1.8 \mathrm{~b}^{2}$ & $12 \mathrm{~b}$ & $3.0 \mathrm{~b}$ & $24 \mathrm{~b}$ & $20.8 \mathrm{a}$ & $47 \mathrm{a}$ & $8.5 \mathrm{~b}$ & $28 \mathrm{~d}$ \\
\hline Hooded windmillgrass (Chloris cucullata) & $7.9 \mathrm{~b}$ & $46 \mathrm{~b}$ & $9.3 \mathrm{ab}$ & $62 \mathrm{a}$ & $12.3 \mathrm{a}$ & $51 \mathrm{ab}$ & $9.8 \mathrm{~b}$ & $53 \mathrm{c}$ \\
\hline Wright's threeawn (Aristida wrightii) & $1.3 \mathrm{~b}$ & $12 \mathrm{~b}$ & $2.0 \mathrm{~b}$ & $18 \mathrm{~b}$ & $8.9 \mathrm{~d} a$ & $40 \mathrm{a}$ & $4.0 \mathrm{c}$ & $23 \mathrm{de}$ \\
\hline Texas bristlegrass (Setaria texana) & $3.2 \mathrm{ab}$ & $27 \mathrm{a}$ & $1.3 \mathrm{~b}$ & $10 \mathrm{~b}$ & $5.6 \mathrm{a}$ & $27 \mathrm{a}$ & $3.4 \mathrm{c}$ & 21 def \\
\hline Plains bristlegrass (Setaria macrostachya) & $2.6 \mathrm{a}$ & $18 \mathrm{a}$ & $0 \mathrm{~b}$ & $4 \mathrm{~b}$ & $0.5 \mathrm{ab}$ & $1 \mathrm{~b}$ & $1.0 \mathrm{c}$ & $8 \mathrm{~g}$ \\
\hline Buffelgrass (Cenchrus ciliaris) & $0.9 \mathrm{~b}$ & $12 \mathrm{a}$ & $1.2 \mathrm{~b}$ & $11 \mathrm{a}$ & $3.9 \mathrm{a}$ & $6 \mathrm{~b}$ & $2.0 \mathrm{c}$ & $10 \mathrm{fg}$ \\
\hline Sand dropseed (Sporobolus cryptandrus) & $1.3 \mathrm{~b}$ & $16 \mathrm{a}$ & $1.0 \mathrm{~b}$ & $12 \mathrm{~b}$ & $3.1 \mathrm{a}$ & $16 \mathrm{a}$ & $1.8 \mathrm{c}$ & $15 \mathrm{efg}$ \\
\hline Four-flowered trichloris (Trichloris pluriflora) & $0.6 \mathrm{a}$ & $6 \mathrm{~b}$ & $1.1 \mathrm{a}$ & $10 \mathrm{a}$ & $0.3 \mathrm{a}$ & $1 \mathrm{c}$ & $0.7 \mathrm{c}$ & $6 \mathrm{~g}$ \\
\hline Arizona cottontop (Trichachne californica) & $2.5 \mathrm{a}$ & $18 \mathrm{a}$ & $1.5 \mathrm{~b}$ & $13 \mathrm{a}$ & $1.3 \mathrm{~b}$ & $3 \mathrm{~b}$ & $1.8 \mathrm{c}$ & 11 efg \\
\hline Pink pappus (Pappophorum bicolor) & $0.8 \mathrm{a}$ & 9 a & $1.4 \mathrm{a}$ & $6 a$ & $0.8 \mathrm{a}$ & $8 \mathrm{a}$ & $1.0 \mathrm{c}$ & $8 \mathrm{~g}$ \\
\hline Miscellaneous grasses & $7.8 \mathrm{~b}$ & $58 \mathrm{~b}$ & $11.4 \mathrm{ab}$ & $89 a$ & $15.7 \mathrm{a}$ & $82 \mathrm{a}$ & $11.7 \mathrm{~b}$ & $76 \mathrm{~b}$ \\
\hline Forbs & $69.3 \mathrm{a}$ & $100 \mathrm{a}$ & $66.8 \mathrm{a}$ & $90 \mathrm{~b}$ & $26.8 \mathrm{~b}$ & $78 \mathrm{c}$ & $54.3 \mathrm{a}$ & $89 \mathrm{a}$ \\
\hline Total plants/ha & \multicolumn{2}{|c|}{630,785} & \multicolumn{2}{|c|}{$1,208.107$} & \multicolumn{2}{|c|}{946,485} & \multicolumn{2}{|c|}{928,459} \\
\hline
\end{tabular}

'Data are averages of two samplings (June and November).

2Values followed by the sample letter are not significantly different within each main treatment and each species at the 0.5 probability level as determined by Duncan's multiple range test. Comparisons for main treatments for both PC and PF of each species are made horizontally. Comparisons for means of species are made vertically. 
Table 5. Herbaceous plant species composition (PC) and plant frequency (PF) of major species for rootplowing (RP), front-ending stacking (S), and control (C) in 1975.

\begin{tabular}{|c|c|c|c|c|c|c|c|c|}
\hline \multirow[b]{2}{*}{ Species } & \multicolumn{2}{|c|}{$\mathrm{RP}(\%)$} & \multicolumn{2}{|c|}{$\mathbf{S}(\%)$} & \multirow[b]{2}{*}{ PC } & \multirow[b]{2}{*}{ PF } & \multicolumn{2}{|l|}{$0 \mathrm{C}(\%)$} \\
\hline & PC & PF & $\mathrm{PC}$ & PF & & & PC & PF \\
\hline Red grama (Bouteloua trifida) & $2.0 \mathrm{~b}$ & $5 \mathrm{c}$ & $4.5 \mathrm{~b}$ & $14 \mathrm{~b}$ & $12.0 \mathrm{a}$ & $24 \mathrm{a}$ & $6.2 \mathrm{cde}$ & $14 \mathrm{def}$ \\
\hline Hooded windmillgrass (Chloris cucullata) & $8.6 \mathrm{c}$ & $26 \mathrm{~b}$ & $29.6 \mathrm{a}$ & $67 \mathrm{a}$ & $12.4 \mathrm{~b}$ & $36 \mathrm{~b}$ & $16.9 \mathrm{~b}$ & $43 \mathrm{~b}$ \\
\hline Wright's threeawn (Aristida wrightii) & $9.1 \mathrm{~b}$ & $26 \mathrm{~b}$ & $9.6 \mathrm{~b}$ & $34 a b$ & $12.8 \mathrm{a}$ & 39 a & $10.5 \mathrm{c}$ & $33 \mathrm{bc}$ \\
\hline Texas bristlegrass (Setaria texana) & $6.5 \mathrm{a}$ & $27 \mathrm{a}$ & $2.1 \mathrm{~b}$ & $14 \mathrm{~b}$ & $8.3 \mathrm{a}$ & $26 \mathrm{a}$ & $5.6 \mathrm{def}$ & $22 \mathrm{~cd}$ \\
\hline Plains bristlegrass (Setaria macrostachya) & $2.0 \mathrm{a}$ & $12 \mathrm{a}$ & $0.2 \mathrm{~b}$ & $4 \mathrm{~b}$ & $0.1 \mathrm{~b}$ & $0.3 \mathrm{c}$ & $0.7 \mathrm{f}$ & $5 \mathrm{f}$ \\
\hline Buffelgrass (Cenchrus ciliaris) & $5.5 \mathrm{a}$ & $19 \mathrm{~b}$ & $4.5 \mathrm{~b}$ & 29 a & $4.5 \mathrm{~b}$ & $21 \mathrm{~b}$ & $4.8 \mathrm{def}$ & $23 \mathrm{~cd}$ \\
\hline Sand dropseed (Sporobolus cryptandrus) & $2.4 \mathrm{~b}$ & $9 \mathrm{~b}$ & $5.5 \mathrm{a}$ & $27 \mathrm{a}$ & $3.2 \mathrm{ab}$ & $14 \mathrm{~b}$ & $3.7 \mathrm{def}$ & $17 \mathrm{def}$ \\
\hline Four-flowered trichloris (Trichloris pluriflora) & $8.2 \mathrm{a}$ & $27 \mathrm{a}$ & $6.4 \mathrm{a}$ & 25 a & $2.4 \mathrm{~b}$ & $9 \mathrm{~b}$ & $5.6 \mathrm{def}$ & $20 \mathrm{de}$ \\
\hline Arizona cottontop (Trichachne californica) & $11.4 \mathrm{a}$ & 37 a & $2.6 \mathrm{~b}$ & $15 \mathrm{~b}$ & $2.4 \mathrm{~b}$ & $11 \mathrm{~b}$ & 5.5 def & $21 \mathrm{de}$ \\
\hline Pink pappus (Pappophorum bicolor) & $1.5 \mathrm{~b}$ & $9 \mathrm{~b}$ & $5.3 \mathrm{a}$ & $20 \mathrm{a}$ & $6.4 \mathrm{a}$ & $21 \mathrm{a}$ & 4.4 def & 17 def \\
\hline Miscellaneous grasses & $9.6 \mathrm{~b}$ & $26 \mathrm{~b}$ & $12.1 \mathrm{a}$ & $48 \mathrm{a}$ & $11.7 \mathrm{a}$ & $40 \mathrm{ab}$ & $13.1 \mathrm{~cd}$ & $38 \mathrm{~b}$ \\
\hline Forbs & $33.2 \mathrm{a}$ & $67 \mathrm{a}$ & $18.0 \mathrm{~b}$ & $67 \mathrm{a}$ & $23.8 \mathrm{ab}$ & $75 \mathrm{a}$ & $25.0 \mathrm{a}$ & $70 \mathrm{a}$ \\
\hline Total plants/ha & \multicolumn{2}{|c|}{604,989} & \multicolumn{2}{|c|}{770,952} & \multicolumn{2}{|c|}{669,791} & \multicolumn{2}{|c|}{681,911} \\
\hline
\end{tabular}

'Data are averages of two samplings (Junc and November).

${ }^{2}$ Values followed by the same sample letter are not significantly different within each main treatment and each species at the 0.5 probability level as determined by Duncan's multiple range test. Comparisons for main treatments for both PC and PF of each species are made horizontally. Comparisons for means of species are made vertically.

Total PC contributed by four remaining seeded species was 30.2 , 18.9 , and $18.5 \%$ for rootplowed, front-end stacking, and the control, respectively. Buffelgrass contributed the highest single species PC for both mechanical manipulation treatments, rootplowed being significantly higher than the control. Arizona cottontop and four-flowered trichloris contributed 7.0 and $9.2 \%$ PC each in rootplowing treatment and were both significantly higher than frontend stacking and the control. Pink pappus contributed the highest PC of the seeded species in the control and was significantly higher than both mechanical manipulation treatments.

\section{Seeding Treatment (sub-treatments)}

The PC\% contributed by seeded and nonseeded grass species and forbs under different seeding treatments following mechanical manipulation treatments and the undisturbed control are shown in Figure 2. Forb PC was high the first year following mechanical treatment rega rdless of seeding treatment, but decreased with time.

Establishment of seeded buffelgrass was faster than any other seeded species on all treatments. In 1973, buffelgrass made slightly more than $2 \%$ of the PC following both manipulation treatments but had increased to about $17 \%$ by 1977 . Seeded buffelgrass was slower in establishing on the control plots. In 1973, 1 year after seeding, buffelgrass accounted for only $1 \%$ of the PC. By 1975 and 1977 buffelgrass increased to 5 and $7 \%$, respectively. It invaded most of the other treatments and in 1977 it was just as common in the nonseeded as in the seeded treatments.
Plains bristlegrass and Arizona cottontop, native seeded species, establish faster than any other species when planted in rootplowed plots. However, by 1977 , plains bristlegrass had completely disappeared and Arizona cottontop decreased in PC from 12\% in 1975 to $6.2 \%$ in 1977 . However, Arizona cottontop invaded other plots and in 1977 it contributed $9.9 \%$ PC in the buffelseeded plots and $6.6 \%$ in the nonseeded plots that had been rootplowed.

Plain bristlegrass never established itself in any of the seeding treatments following front-end stacking or the control. Pink pappusgrass established itself better in all seeding treatments of the control than either of the mechanical manipulation treatments. It invaded the plots where it was not seeded and in 1977 contributed 7.8 and $6.5 \%$ of the PC in buffelgrass seeded and nonseeded treatment, respectively.

Four-flower trichloris was slow in establishment, but by 1975 it contributed at least $11 \%$ of the PC in both mechanical manipulation treatments where it had been seeded. By 1977, four-flower trichloris contributed $13.8 \%$ of the PC in the rootplowed treatment where it was seeded, $4.5 \%$ in the buffelseeded plots, and $9.3 \%$ in the nonseeded plots.

Plant species composition contributed by nonseeded grass species in the nonseeded treatment of rootplowed plots was 27,43 , and $36 \%$ in 1973, 1975, and 1977, respectively. Red grama and Wright's threeawn were reduced the most in rootplowed plots, while hooded windmill increased and Texas bristlegrass was unaffected. Some important annual and perennial grasses also appeared: southwest-

Table 6. Herbaceous plant species composition (PC) and plant frequency (PF) of major species for rootplowing (RP), front-ending stacking (S), and control (C) in 1977.

\begin{tabular}{|c|c|c|c|c|c|c|c|c|}
\hline \multirow[b]{2}{*}{ Species } & \multicolumn{2}{|c|}{$\mathrm{RP}(\%)$} & \multicolumn{2}{|c|}{$\mathrm{S}(\%)$} & \multirow[b]{2}{*}{ PC } & \multirow[b]{2}{*}{ PF } & \multicolumn{2}{|l|}{$0 \mathrm{C}(\%)$} \\
\hline & $\mathrm{PC}$ & $\mathrm{PF}$ & PC & PF & & & $\mathrm{PC}$ & PF \\
\hline Red grama (Bouteloua trifida) & $0.8 \mathrm{~b}$ & $3 \mathrm{c}$ & $3.0 \mathrm{~b}$ & $12 \mathrm{~b}$ & $15.7 \mathrm{a}$ & $28 \mathrm{a}$ & $6.5 \mathrm{~cd}$ & 14 ef \\
\hline Hooded windmillgrass (Chloris cucullata) & $11.6 \mathrm{~b}$ & $33 \mathrm{~b}$ & $28.6 \mathrm{a}$ & $70 \mathrm{a}$ & $11.2 \mathrm{~b}$ & $44 \mathrm{~b}$ & $17.1 \mathrm{~b}$ & $49 \mathrm{~b}$ \\
\hline Wright's threeawn (Aristida wrightii) & $6.2 \mathrm{~b}$ & $31 \mathrm{~b}$ & $8.6 \mathrm{~b}$ & $39 \mathrm{a}$ & $12.6 \mathrm{a}$ & $43 \mathrm{a}$ & $9.1 \mathrm{c}$ & $38 \mathrm{c}$ \\
\hline Texas bristlegrass (Setaria texana) & $7.4 \mathrm{a}$ & 33 a & $0.8 \mathrm{~b}$ & $7 \mathrm{~b}$ & $6.5 \mathrm{a}$ & $26 \mathrm{a}$ & $4.9 \mathrm{de}$ & 22 def \\
\hline Plains bristlegrass (Setaria macrostachya) & - & - & - & - & - & - & - & - \\
\hline Buffelgrass (Cenchrus ciliaris) & $11.8 \mathrm{a}$ & $37 \mathrm{ab}$ & $8.9 \mathrm{ab}$ & $44 \mathrm{a}$ & $7.3 \mathrm{~b}$ & $34 \mathrm{~b}$ & $9.3 \mathrm{c}$ & $38 \mathrm{c}$ \\
\hline Sand dropseed (Sporobolus cryptandrus) & $2.5 \mathrm{~b}$ & $18 \mathrm{~b}$ & $7.6 \mathrm{a}$ & $37 \mathrm{a}$ & $3.1 \mathrm{~b}$ & $16 \mathrm{~b}$ & $4.4 \mathrm{de}$ & $24 \mathrm{de}$ \\
\hline Four-flowered trichloris (Trichloris pluriflora) & $9.2 \mathrm{a}$ & $40 \mathrm{a}$ & $5.3 \mathrm{~b}$ & $27 \mathrm{~b}$ & $2.1 \mathrm{c}$ & $9 \mathrm{c}$ & $5.5 \mathrm{de}$ & $25 \mathrm{de}$ \\
\hline Arizona cottontop (Trichachne californica) & $7.0 \mathrm{a}$ & 33 a & $1.3 \mathrm{~b}$ & $10 \mathrm{~b}$ & $1.6 \mathrm{~b}$ & $10 \mathrm{~b}$ & $3.3 \mathrm{de}$ & 18 ef \\
\hline Pink pappus (Pappophorum bicolor) & $2.0 \mathrm{~b}$ & $13 \mathrm{~b}$ & $3.4 \mathrm{a}$ & $19 \mathrm{ab}$ & $7.5 \mathrm{a}$ & $27 \mathrm{a}$ & $4.3 \mathrm{de}$ & $20 \mathrm{def}$ \\
\hline Miscellaneous grasses & $9.4 \mathrm{a}$ & $25 \mathrm{~b}$ & $8.9 \mathrm{a}$ & $34 \mathrm{a}$ & $7.1 \mathrm{a}$ & $31 \mathrm{ab}$ & $8.6 \mathrm{c}$ & $30 \mathrm{~cd}$ \\
\hline Forbs & $32.1 \mathrm{a}$ & $78 \mathrm{~b}$ & $23.6 \mathrm{~b}$ & $86 \mathrm{a}$ & $25.3 \mathrm{~b}$ & $87 \mathrm{a}$ & $27.0 \mathrm{a}$ & $84 \mathrm{a}$ \\
\hline Total plants/ha & \multicolumn{2}{|c|}{429,540} & \multicolumn{2}{|c|}{613,390} & \multicolumn{2}{|c|}{515,840} & \multicolumn{2}{|c|}{519,590} \\
\hline
\end{tabular}

'Data are averages of two samplings (June and November).

2Values followed by the sample letter are not significantly different within each main treatment and each species at the 0.5 probability level as determined by Duncan's multiple range test. Comparisons for main treatments for both PC and PF of each species are made horizontally. Comparisons for means of species are made vertically. 
Box 1967). In areas cleared and seeded to climax or introduced grass species, however, good stands were established, and by the second year, desirable forage had increased.

Buffelgrass, an introduced seeded species, was the most aggressive species. This species accounted for a major portion of forage in the plots where it was seeded. By 1977, it had invaded all treatments and accounted for a high portion of the forage in all treatments. Buffelgrass invasion on all treatments indicated a rapid response to available soil moisture. Indications were that its competitive capability was equal to or greater than that of other perennial grasses in the study. Even though buffelgrass PC was low in all treatments, this species by itself contributed more than $50 \%$ of the total forage production by weight in all treatments (Gonzalez and Dodd 1979). This plant is robust, large, and produces much biomass.

The contribution to PC by three seeded native grass species (pink pappus, plains bristlegrass, and Arizona cottontop) was generally high the first three years after treatment and then decreased with time. Plains bristlegrass was completely absent by the fourth year. This probably reflected selective grazing. Fourflower trichloris, like buffelgrass, increased in PC with time on plots subjected to both mechanical treatments. Grazing animals, however, did not utilize this species as much as other species. The order of cattle consumption for the seeded species was observed to be buffelgrass $>$ plains bristlegrass $>$ Arizona cottontop and pinkpappus $>$ four-flower trichloris.

Species composition of volunteer nonseeded grasses was reduced the first year after mechanical manipulation as compared with the control $(23 \%$ vs $70 \%)$. By the third year, however, $63 \%$ of the composition in the front-end stacked treatment and $38 \%$ in the rootplowed treatment was made up of nonseeded speices. Little change occurred in PC by nonseeded species from 1975 to 1977, indicating a trend toward a stable plant community.

\section{Conclusions}

Clearing and seeding of southern Texas rangeland increases grass species composition. With time and proper management, there should be a shift from annual forbs and annual grasses to desirable perennial grasses. Management considerations are necessary, however, in deciding which woody species should be preserved. More information is needed in southern Texas to determine livestock and wildlife preferences with regard to utilization of woody plants.

Change in grass composition from native species to buffelgrass will probably occur any time buffelgrass is introduced into the native stand. Observations from this study indicated that cattle prefer buffelgrass and utilized it more than native grasses. More- over, its rapid growth and recovery after rainfall promotes its capacity to dominate and invade native grass stands. Buffelgrass should not be seeded, however, if diverse rangeland including many native perennial grasses is desired.

\section{Literature Cited}

Canfield R.H. 1942. Application of the line intercept method in sampling range vegetation. J. Forestry. 39:338-394.

Cockran, W.G., and G.M. Cox. 1956. Experimental Designs. John Wiley and Sons, Inc., New York. 454 p.

Correll, D.S., and M.C. Johnston. 1970. Manual of the Vascular Plants of Texas. Texas Research Foundation, Renner, Texas. 1881 p.

Dix, R.L. 1961. An application of the point-centered quarter method to the sampling of grassland vegetation. J. Range Manage. 18:190-194.

Fisher, C.E., C.H. Meadors, R. Behrens, E.D. Robinson, P.T. Marion, and H.L. Morton. 1959. Control of mesquite on grazing lands. TAMU. Texas Agr. Exp. Sta., College Station, Texas. Bull. 935.

Gonzalez, C.L., and J.D. Dodd. 1979. Production response of native and introduced grasses to mechanical brush manipulation, seeding, and fertilization. J. Range Manage. 32:305-309.

Gould, F.W. 1975. Texas plants: A checklist and ecological summary. TAMU. Texas Agr. Exp. Sta., College Station, Texas. 121 p.

Hughes, E.E. 1966. Effects of rootplowing and aerial spraying on microclimate, soil conditions, and vegetation of a mesquite area. Texas Agr. Exp. Sta. Misc. Pub. 812.

Inglis, J.M. 1964. A history of vegetation on the Rio Grande Plains. Texas Parks and Wildlife Dept. Bull. 45. 122 p.

Jaynes, C.C., E.D. Robinson, and W.G. McCully. 1968. Rootplowing and revegetation on the Rolling and Southern High Plains. TAMU. Texas Agr. Exp. Sta., College Station, Texas. Prog. Rep. 2584.

Johnston, M.C. 1963. Past and present grasslands of southern Texas and northestern Mexico. Ecology. 44:456-466.

Lehmann, V.W. 1965. Fire in the range of Attwater's prairie chicken. Proc. Fourth Annual Tall Timbers Fire Fcology Conf. 127-143.

Mathis, G.W., M.M. Kothmann, and W.J. Waldrip. 1971. Influence of rootplowing and seeding on composition and forage production of native grasses. J. Range Manage. 24:43-47.

Powell, J., and T.W. Box. 1967. Mechanical control and fertilization as brush management practices affect forage production in south Texas. J. Range Manage. 20:227-235.

Smith, H.N., and C.A. Rechenthin. 1964. Grassland restoration: the Texas brush problem. Unnumbered Bull. USDA, Soil Conserv. Serv., Temple, Texas. p. 139.

Texas Conservation Needs Committee. 1974. Conservation needs inventory, Texas. U.S. Dep. Agr. Soil Conserv. Serv., Temple, Texas.

U.S. Dep. Commerce. 1970. Climatological Summary. Brownsville, Texas. $46 \mathrm{p}$.

Vines, R.H. 1960. Trees, shrubs, and woody vines of the Southwest. U. Texas Press, Austin. 1104 p. 